\title{
First Report of Fruit Rot of Ridge Gourd (Luffa acutangula) Caused by Sclerotium rolfsii
}

\begin{abstract}
Chandrasekar S. Kousik and Jennifer Ikerd, U.S. Vegetable Laboratory, USDA, ARS, 2700 Savannah Highway, Charleston, SC 29414; and Mihir Mandal, ORISE participant sponsored by the U.S. Vegetable Laboratory, USDA, ARS, 2700 Savannah Highway, Charleston, SC 29414
\end{abstract}

Accepted for publication 12 January 2016. Published 14 January 2016.

Kousik, C. S., Ikerd, J., and Mandal, M. 2016. First report of fruit rot of ridge gourd (Luffa acutangula) caused by Sclerotium rolfsii. Plant Health Prog. 17:18-19.

Ridge gourd (Luffa acutangula) is a specialty cucurbit vegetable cultivated in the United States on a small scale for select markets (Molinar 2012). Ridge gourds are generally grown on a trellis which prevents the fruit from curving and allows it to grow straight, which is preferred for the market. However some growers cultivate these on raised beds to lower production costs. Our research program has been planting specialty cucurbits for the past 5 years to monitor pathotypes and races of the cucurbit powdery mildew pathogen. Nineteen rainy days in Charleston, SC, during the month of September 2014 resulted in 11 inches of rainfall that led to considerable rot $(25 \%)$ of the fruit of ridge gourd variety Surekha (Fig. 1A) in our research plots. Most fruits in contact with the soil exhibited symptoms of rot. Although occurrence of fruit rots in Luffa spp. in general were mentioned earlier, causal organisms were not specified (Davis 1994; Molinar 2012). Visual examination of rotting fruit revealed the presence of sclerotia on the fruit surface (Fig. 1B) and the pathogen was identified as Sclerotium rolfsii (teleomorph: Athelia rolfsii). The pathogen was isolated by placing edges of rotting lesions, mycelial bits, or sclerotia from rotting fruits on acidified potato dextrose agar (APDA). Sclerotia and mycelium were macerated in sterile distilled water using a BeadBeater (BioSpec, Bartlesville, $\mathrm{OH}$ ) and directly used in PCR reactions as per GoTaq master mix protocol (Promega, Madison, WI). The ITS region was amplified using ITS1 and ITS4 primers (White et al. 1990). The ITS fragment was cloned using TOPO cloning kit (Invitrogen, Carlsbad, CA) and sequenced. The sequence (submitted to the NCBI GenBank database as Accession No. KU128903) was 99 to $100 \%$ identical to Athelia rolfsii sequence in GenBank (Accession Nos. GU080230.1, HQ420816.1, and KJ546416.1). In addition, primers were designed using known $A$. rolfsii sequences in the database for the lectin gene and translation elongation factor 1alpha (TEF1). The primers were used to PCR amplify these regions of $S$. rolfsii isolate from ridge gourd. PCR-amplified fragments were cloned and sequenced, and the sequences were 99 to $100 \%$ identical to $A$. rolfsii TEF1 (GU187681.1, JF267817.1, and KP982854.1) and 98\% to lectin gene (JN811676.1 and FJ211419.1) in the GenBank database further confirming the identity of the pathogen. The sequences for $S$.

Corresponding author: C. S. Kousik (Shaker). Email: shaker.kousik@ars.usda.gov.

doi:10.1094/PHP-BR-15-0048

(C) 2016 The American Phytopathological Society

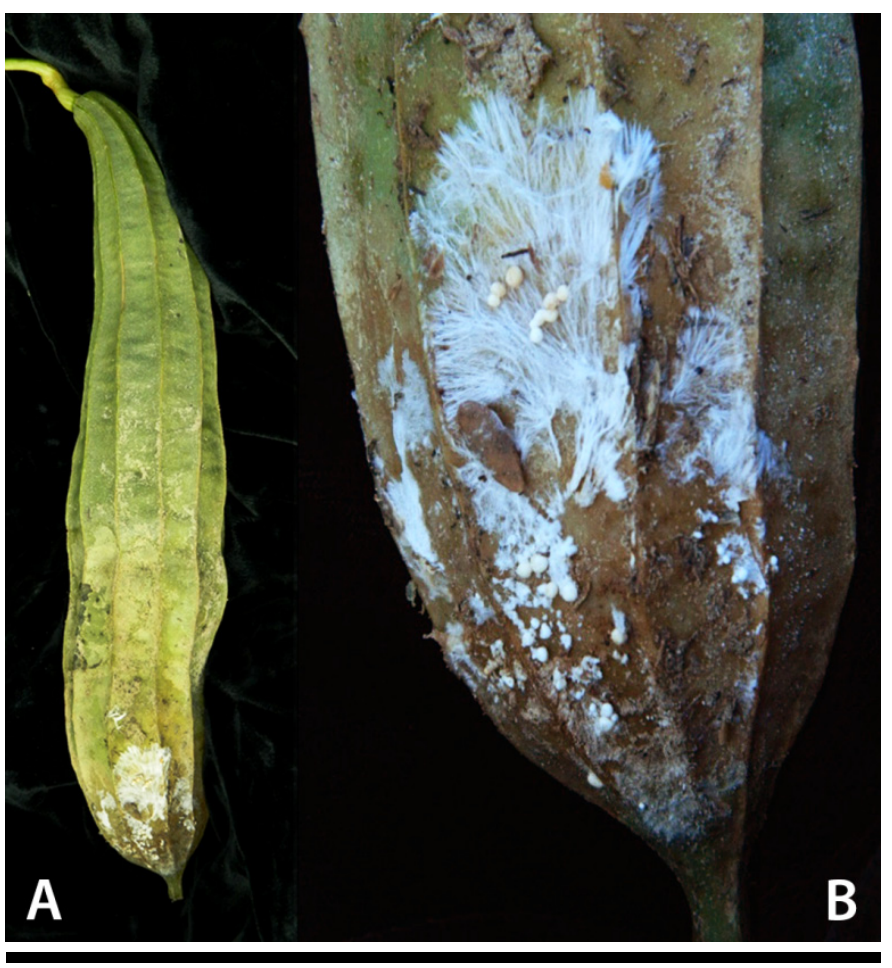

FIGURE 1

(A) Ridge gourd fruit naturally infected by Sclerotium rolfsii in a field, Charleston, SC, September 2014. (B) Close up of infected area of ridge gourd fruit collected from the field in Charleston, SC. Spherical sclerotia and mycelium of S. rolfsii can be observed on the fruit surface.

rolfsii isolated from ridge gourd have been submitted to GenBank with Accession Nos. KU128904 (lectin gene) and KU128905 (TEF1). Symptomless ridge gourd fruits (approximately 3 to 4 week old) were surface sterilized and inoculated with four sclerotia per fruit placed at the blossom end of the fruit, as most of the infection in the field was observed in this area. The sclerotia were obtained from an actively growing colony on APDA plate. There were six fruits per replication with four replications. Inoculated fruits were placed on shelves in a humid chamber $\left(>95 \% \mathrm{RH}, 26 \pm 2{ }^{\circ} \mathrm{C}\right)$. Five days after inoculation, $87 \%$ of the fruit were infected and symptoms similar to those observed in the field were noticed. No infection or rotting symptoms were observed in non-inoculated areas of the fruit or on non-inoculated fruits. Additionally, autoclaved 
sclerotia used as controls did not induce rotting of fruit. The pathogen was easily re-isolated from the inoculated fruits. The experiments were repeated two more times with similar results. Southern blight and fruit rots caused by Sclerotium rolfsii has been reported on cucurbits such as melon and watermelon (Bruton 1996). To the best of our knowledge we have not come across reports of Sclerotium rot of ridge gourd in the United States or elsewhere in the world. In fields with a history of $S$. rolfsii, the gourds should be grown on trellis to prevent fruit from coming in contact with wet soil. Fungicides are available and labelled for managing $S$. rolfsii on cucurbits, including Luffa spp., and may have to be applied when and if necessary.

\section{LITERATURE CITED}

Bruton, B. D. Southern blight. Page 56 in: Compendium of Cucurbit Diseases. T. A. Zitter, D. L. Hopkins, and C. E. Thomas, eds. APS Press, St. Paul, MN.

Davis, J. M. 1994. Luffa sponge gourd production practices for temperate climates. HortScience 29:263-266.

Molinar, R. H. 2012. Indigenous Asian specialty vegetables in the central valley of California. HortScience 47:835-838.

White, T. J., Bruns, T., Lee, S., and Taylor, J. W. 1990. Amplification and direct sequencing of fungal ribosomal RNA genes for phylogenetics. Pages 315-322 in: PCR Protocols: A Guide to Methods and Applications, eds. M. A. Innis, D. H. Gelfand, J. J. Sninsky, and T. J. White, eds. Academic Press, Inc., New York. 